the wound had taken place. I saw her frequently till the 28th, when she was sitting up, and said she felt quite well. I attribute the success of this case to the dry dressings, the position of the patient, and the immediate surgical treatment of the wound. Her temperature never rose over $1005^{\circ}$. De Beauvgir-road, $\mathbf{N}$.

\section{TWO CASES OF DISLOCATION AT THE SHOLLDER JOINT REDUCED BY KOCHER'S METHOD.}

By Clarence Beesley, L.Iu.C.P. \& S., \&c.

THE following cases of dislocation at this joint, reduced by Kocher's method, may prove of interest to those of my professional brethren who have not tried this plan.

CASE 1. - The subject of this case was a young man, aged twenty, who, two years previously, had suffered from a dislocation which was treated by a French surgeon with the "heel in the axilla." When I saw the patient he was suffering from a subcoracoid dislocation, and he was much pleased at the rapid and easy manner in which it was aeduced by the above plan.

CASE 2.-This patient was a man, aged sixty-five, who had dislocated his shoulder by a fall from a ladder. I saw him shortly after the accident, and found a subglenoid luxation. This was also very easily reduced by the same method, which, I may ald, consists in first flexing the forearm on the arm, gently pressing the elbow to the side, rotating the humerus outwards, until the forearm is at right angles to the body, and then raising the elbow from the body and rotating it inwards until the hand reaches the opposite shoulder. Newhaven, Sussex.

\section{de thitrur}

OF

\section{HOSPITAL PRACTICE, BRITISH AND FOREIGN.}

Nulla autem est alia pro certo noscendi via, nisi quamplurimas et morSorum et dissectionum historias, tum aliorum tum proprias collectas Sorum et dissectionum historias, tum aliorum tum proprias collectas habere, et inter se

\section{VICTORIA HOSPITAL FOR CHILDREN, CHELSEA.}

A CAST OF ACUTE NEPHRITIS AND UR IMIC CONVULSIONS ; COMPLETE RECOVERY ; REMARKS.

(Under the care of Dr. J. WALTER CARR.)

AxTHOUGH recovery from a condition of acute inflammation of the kidneys in a child is not uncommon even when evidence of uræmic poisoning of the system is present, ${ }^{1}$ we consider that the publication of a well-marked case of the disease, in which special syniptoms were carefully noted, will be of interest to the profession. Dr. Carr has drawn attention in his remarks to the more important points in the case, such as the absence of dropsy and the presence of cardiac enlargement. The condition of the urine, the specific gravity, and absence of albumen and casts indicated the completeness of the recovery. Pilocarpine was, as usual in children, well borne; it would, however, be as well for our readers to remember its occasional depressing action on the heart.

H. M- , aged six years, was admitted on Feb. 10th, 1889 , at 7.30 P.M. The following history was obtained, partly at the time and partly subsequently. He had had measles three years before. There was no history of scarlet fever or of anything pointing to it; no history of chill or of exposure to cold. He had been ailing for a week with headache, chilliness, and slight cough, and had complained of pain below the left nipple. No pain in the loins; no wema at any time. Bowels irregular; urine thick, red, and scanty ; micturition frequent. On Feb. 10th, the day of admission, he was very sick from $4 \mathrm{~A}$.M. to $11 \mathrm{~A}$.M. ; he then became unconscious, and between 1 P.M. and 3 P.M. had five convulsive attacks; he then slept till 5 P.M., and afterwards had a screaming fit.

1 Eustace Smith: Diseases of Children, p. 41. Wright and Ashby, p 226. Saundby: Lectures on Bright's Disease, p. 61 .
On admission his condition closely resembled that described as "cerebral irritation." He lay on his side, coiled up in bed, restless, and screaming out when touched. Temperature $98.4^{\circ}$. No odema; no desquamation any where. At 9.10 P.M. he had a convulsive attack; pupils dilated, insensible to light, no conjunctival reflex; spasms alternately more on one side than the other. 'Temperature $100 \cdot 4^{\circ}$ (in rectum). The diagnosis at this time being very uncertain, the house surgeon, Mr. Staveley, drew off three ounces of urine by catheter. This was found to contain nearly half albumen, a trace of blood, and some uricacid crystals, sp. gr. 1020 . Accordingly, as the convulsions continued, one-tenth of a grain of pilocarpine was injected, patient placed in a hot bath, and afterwards wrapped in blankets. Much sweating followed, the convulsive attacks became less severe, and by 11 P.M. had entirely ceased. They did not recur. A dose of compound jalap powder was administered, but speedily vomited. Ten grains of bromide of potassium and five grains of chloral hydrate were given per rectum, and patient slept well afterwards. Temperature : 2 A.M., $102 \cdot 8^{\circ} ; 6$ A.M., $100.8^{\circ}$; 10 A.M., $986^{\circ}$; rose once to $100^{\circ}$ next day, but never afterwards above $99^{\circ}$. Bowels acted well during the night. Next morning the patient was quite conscious and free from sickness. After midday he began to take food and to pass urine for the first time since admission.

On further examination he was found to be a wellnourished boy, pale, and with rather dry skin; tongue thickly furred. Heart's apex beat in fifth space half an inch outside nipple-line ; impulse markedly forcible; slight epigastric pulsation. Cardiac dulness began at third rib, cartilage end, along middle line of sternum; sounds normal; no distinct accentuation of second sound. Pulse hard and rather incompressible. A few scattered râles in lungs. No ophthalmoscopic changes visible. Urine for the twantyfour hours: acid, sp. gr. 1022, albumen $\frac{1}{6}$, urea 13 per cent., a large deposit consisting of aumerous epithelial, granular, and hyaline casts, red blood-corpuscles, renal epithelial cells and uric-acid crystals. He has been sweating freely each night, and bowels well open.

Feb. 15.-Heart's apex beat in fourth space just outside nipple, impulse much less forcible, and pulse much more compressible. Urine contains no blood, and only a faint trace of albumen. After this the boy continued to make an uninterrupted recovery, the tongue slowly cleaned, and food was always taken well. The urine passed per diem varied in quantity from twenty to thirty-five ounces; sp. gr. 1015-30; generally no albumen, but occasionally a very faint trace. The casts gradually got fewer in number, and the process of disintegration of epithelial into granular ones was well seen; uric-acid crystals persisted for a long time, but completely disappeared before the patient was discharged. He was kept exclusively on milk and barley water until Feb. 17th, when nilk pudding was first given; bread-and-milk on Feb. 21st, fish on March 14th, and meat on March 18th.

March 2ist.- He got up. The bowels were lept freely open throughout by frequent doses of saline aperients. After Feb. 16th citrate of iron and quinine (two grains) was given three times a day.

He was discharged on March 29 th, looking stout and well. Heart's apex beat in the fourth space in the nipple-line, normal in character. Pulse not of high tension. Urine for the twenty-four hours: sp. gr. 1022, urea 26 per cent., albumen a very faint trace, no casts.

Oct. 11th.-Patient, seen to-day, is in good health. In recumbent position the heart's apex beat is in the fourth space; in the erect posture it can just be felt in the fifth space in the nipple-line. No albumen in urine.

Remarks by Dr. CARR - The leading features of clinical and theoretical interest in this case may be summarised as follows:-1. As to the cause of the nephritis nothing definite could be made out, a much less common occurrence in children than in adults. Whilst the history seemed altogether to exclude scarlet fever, yet the character of the illness and the rapid and complete recovery under treatment point to an acute attack of nephritis uncomplicated by any chronic renal disease, and to the scarlatinal form rather than to the more intractable variety due to chill. 2. The case illustrates the statement of Dr. Saundby 2 that uramic convulsions and vomiting are not of very serious significance in the acute nephritis of children. 3 . The rapid rise of temperature with-and 